\title{
Metacognitive Awareness Instruction: A Mixed Method Study on High School EFL Learners' Writing Develop- ment
}

Instrucción de concienciación metacognitiva: un estudio de método mixto sobre el desarrollo de escritura de los aprendices EFL de la escuela secundaria

Mahdieh Akbarzadeh

Islamic Azad University, Kerman, Iran.

ORCID: https://orcid.org/0000-0001-5220-357X

Massoud Tajadini*

Islamic Azad University, Kerman, Iran.

ORCID: https://orcid.org/0000-0001-5007-2289

Mehry Haddad Narafshan

Islamic Azad University, Kerman, Iran.

ORCID: https://orcid.org/0000-0001-9399-4750

Received 06-14-20 Revised 08-10-20 Accepted 09-01-20 On line 09-30-20

*Correspondence

Email: massoud_taj@yahoo.com
Cite as:

Akbarzadeh M. Tajadini M., \& Haddad Narafshan M. (2020). Metacognitive Awareness Instruction: A Mixed Method Study on High School EFL Learners' Writing Development. Propósitos $y$ Representaciones, 8 (SPE3), e757. Doi: http://dx.doi.org/10.20511/pyr2020.v8nSPE3.757 


\section{Summary}

The goal of this study was to investigate the impact of using metacognitive awareness instruction (MAI) on EFL learners' writing skill. To follow this goal, a research questions were designed and proposed. The questions sought to explore the impact of using metacognitive awareness instruction on the writing performance of the learners. To achieve this goal, two groups of high school EFL learners established the participants of the study. To collect the data of the study, three instruments were used: a test of homogenization, pre and post writing tests and finally intrinsic motivation questionnaire developed and examined by (Renee Payne, 2007). The achievements of the study indicated the positive impact of using MAI on the writing improvement of the learners.

Keywords: metacognitive awareness, writing, EFL.

\section{Resumen}

El objetivo de este estudio fue investigar el impacto del uso de la instrucción de conciencia metacognitiva (MAI) en la habilidad de escritura de los estudiantes de EFL. Para seguir este objetivo, se diseñaron y propusieron preguntas de investigación. Las preguntas buscaban explorar el impacto del uso de la instrucción de conciencia metacognitiva en el rendimiento de escritura de los alumnos. Para lograr este objetivo, dos grupos de estudiantes de EFL de secundaria establecieron a los participantes del estudio. Para recopilar los datos del estudio, se utilizaron tres instrumentos: una prueba de homogeneización, pruebas previas y posteriores a la escritura y finalmente un cuestionario de motivación intrínseca desarrollado y examinado por (Renee Payne, 2007). Los logros del estudio indicaron el impacto positivo del uso de MAI en la mejora de la escritura de los alumnos.

Palabras clave: conciencia metacognitiva, escritura, EFL.

\section{Introduction}

In spite of a proliferation of methods to teach another language (Richards \& Schmidtm, 2010), it is clear that attempts to find a method that will suit all types of learners have so far had little success. Recent interest in cognitive psychology has stressed the importance of taking account of what is happening in the learner's head and how they view learning, since learners are not just an empty box, but are actively involved in the teaching-learning process and have their own attitudes towards teaching-learning components in terms of selecting an appropriate teaching method and its principles that can suit their personal properties. They have different needs when learning a foreign language and choose their own learning strategies and approaches. This has led to an increasing awareness of the fact that individual differences in learning need to be accounted for, one important of which is the motivation the learners bring to the teaching situation and the other is the level of metacognitive awareness of the learners (Skehan, 1989) and (Riding \& Rayner, 2000) and (Ehrman, 1996).

Metacognition is defined as cognition about cognition or simply thought about the thought, has become a major field of enquiry in cognitive and developmental psychology $(\ddot{\mathrm{O} z}, 2005)$ and is recognized to affect cognition of human beings in various ways. The construct of metacognition has also been recognized as having a great importance in learning (Flavell, 1987). Metacognitive awareness means being aware of how you think. In the ELT classroom, it means being aware of how you learn. Developing metacognitive awareness is an important part of helping learners become more effective and, importantly, more autonomous. If learners are conscious of how they learn, then they can identify the most effective ways to learn more effectively with higher motivation. One of the most effective and easiest ways to develop metacognitive awareness is simply talking with learners about how they do things in the classroom, such as recording new words, reading a text, and laying out a page in their notebooks. The goal of this study is assisting the learners in the writing class to enhance their metacognitive awareness. The goal is introducing the teaching procedures in the writing class being based on improving and fostering the metacognitive awareness of the learners. 


\section{Research Questions}

To investigate the impact of metacognitive awareness in the writing class, the following three directional questions were raise:

What is the impact of metacognitive instruction on high school EFL learners' writing skill?

\section{Literature Review}

Metacognitive Awareness: A Definition

Metacognition comprises two main categories: knowledge of cognition and regulation of cognition (Schraw, 1998). Knowledge of cognition refers to what individuals know regarding their own mental processing and includes declarative, procedural and conditional awareness; that is, knowing about things, knowing the way to do things, and knowing about the reason why and the opportunity to do things. Regulation of cognition refers to all the actions the learners take in order to control their learning and involves skills in planning, monitoring, and assessing their own progress in learning (Schraw, 1998). Hence, metacognitive knowledge is the knowledge about learning that learners of different ages and different learning proficiency hold, and which influences how they face the language learning process and the expectations they have about the results of their efforts (Wenden, 1998). This knowledge includes knowing about the factors that can either facilitate or inhibit their learning, which they will normally gain from their own experiences as language learners; knowledge about aspects regarding the language task at hand (purpose and usefulness, nature and demands posed to accomplish it); knowledge about the learning process itself, including strategic knowledge such as language learning strategies, their specific use and the way and form in which they can be used. In this way, the concept of metacognitive knowledge is used interchangeably with that of metacognitive awareness. However, it is my contention that the concept of metacognitive awareness has the added implication of 'consciousness' which the former does not necessarily have. This is because metacognitive knowledge may also have become automated to the point that bringing it out may require a conscious effort. It is this concept that I find most useful and hence the one I will be referring to more frequently throughout this thesis.

\section{Metacognitive Theories}

By a metacognitive theory we mean a theory of cognition. Metacognitive theories are a subset of theories of mind in that the class of all theories of mind includes, but is not limited to, theories of cognition. Theories of mind address mental phenomena such as emotion, personality, and so forth (Flavell, 1997). Metacognitive theories are those theories of mind that focus on cognitive aspects of the mind. In theorizing about cognition, individuals create and synthesize meta-cognitive knowledge. It is crucial, however, to distinguish (a) the structured knowledge that comprises a theory from (b) the phenomena the theory is about. All theories are cognitive in that they are structures of knowledge, but not all theories are about cognition. Metacognitive theories are theories about cognition. As such, they comprise metacognitive knowledge but they are not necessarily about such knowledge. Rather, theories about metacognition would constitute meta-metacognitive knowledge. Such theories represent only a subset of metacognitive theories (Brown, 1987). 


\section{Metacognitive Awareness Training}

Metacognitive awareness has been viewed as an important aid that can lead to successful foreign language learning and learner autonomy appears to be a desirable outcome of studies that have looked at these issues in many contexts. However, it represents a big challenge for contexts with a historical background of traditional language teaching and settings, such as Chile. In fact, several authors acknowledge that being conscious of their learning processes helps learners to plan, organize and assess their learning, and in doing so, they become more autonomous and self-sufficient (Wenden \& Rubin, 1987) and (Schraw \& Denison, 1994); (Oxford, 1990) and (Cohen, 1998). However, metacognitive awareness is not an independent variable in this process but rather one of a series of variables that inter-relate and contribute to successful (or unsuccessful) language learning. Some relate to the cognitive domain, e.g. metacognitive awareness, language learning strategies, learning styles, aptitude; some to the social-affective domain, e.g. motivation, personality, anxiety and tolerance of ambiguity; and some to the contextual domain. The inter-relatedness of all these variables is shown in the following diagram, where the three sets combine, leading to the development of autonomy and, given positive interactions and contributions, to successful language learning.

\section{The Role of Metacognitive Awareness in Writing}

After the shift of paradigm towards progressive education and under the influence of cognitivism, education witnessed a marked emphasis on experiential learning (Gold et al., 2012) and problem solving (Mohanty, 2007). There has been a move toward process-oriented theories of writing which is, as (Hairston, 1982) claims, a paradigm shift in composition theory. In the new perspective, writing is viewed as a process of creation of meaning in which the writer gets involved in the recursive process of preparing the draft, revising and checking.

Under the influence of cognitive psychology on models of writing in early 1980s, the writers' mental processes gained prominent importance (Johns, 1990). In a short time, terms which had been borrowed from cognitive psychology found their place in the description of writers' mental processes. This trend gave birth to process-based models of writing. These models began to examine anew the act of composing. Among these models the most notable ones were developed by (Hayes \& Flower, 1980) and (Bereiter \& Scardamalia, 1987). Both models consider writing as problem solving act and a higher order mechanism which deal with the constraints while writing.

In (Hayes \& Flower, 1980) model, it is assumed that writing is basically a problemsolving activity. Problem solving in this model means that the writer has to tackle the ongoing problem of formulating, organizing, and producing text. To put it simply, the problem for a writer is the act of producing the text for which he has to set goals and find a solution. To do so, based on Hayes and Flower's model, writers has to constantly make decisions regarding their cognitive recourses (Wong, 1991). This necessitates the use of a higher order process which seems to control cognitive processing.

In (Hayes \& Flower, 1980) model, the monitor assumes such a responsibility and checks the progress of planning, translating and reviewing. Therefore, although not explicitly stated in the model, the monitor plays the role of metacognitive awareness.

\section{Teaching Writing Metacognitively}

Even though external guidance and support can assist learners in performing literacy skills, selfquestioning and self-monitoring are believed to better assist language learners to plan, monitor, and evaluate their reading and writing processes (Hartman, 2001) and (Jacobs \& Paris, 1987). When EFL writing instructors have a big class as the instructors in China do, training students 
to become independent learners who possess metacognitive strategic knowledge for writing and for regulating their own writing should be helpful to solve some of the problems caused by the large class size and to improve students' writing proficiency. This paper, therefore, encourages EFL writing instructors to teach for meta-cognition so as to develop and enhance students' metacognitive models and awareness. With her Chinese students, (Wu, 2003) conducted an empirical study to propose teaching principles of EFL writing. The study confirmed Flavell's theoretical framework of metacognition which consisted of metacognitive knowledge and metacognitive experiences and yielded important pedagogical implications for researchers.

Here three guidelines for EFL writing instructors who plan to teach for metacognition in their writing classrooms on the basis of the abundant literature that explicates the approaches promoting readers' metacognitive awareness. There are mainly two reasons for providing only the guidelines. First, one general guideline may sometimes involve more than one activity or strategy.

For instance, when practicing scaffolded instruction in the classroom, EFL writing teachers can adopt teacher modeling, thinking-aloud, self-questioning, and cooperative learning at the same time. Second, a creative teacher can design and develop more and new activities by following the guideline without being restricted by a limited set of activities.

\section{Motivation in EFL Context}

Various factors are involved when it comes to second language acquisition (SLA) in general and English as a second language (ESL) in particular, one of which is motivation. In SLA, it refers to the attempt and desire to learn a language and positive attitudes toward learning it (Dornyei \& Clement, 2001). However, studying motivation is important to many SLA researchers because it is believed that without sample motivation, even learners with the most notable abilities cannot achieve long term goals. In other words, appropriate curricula and good instruction might not be enough to guarantee success.

\section{Results}

\section{Participants}

The population of the study was composed of all high school learners in a school in Kerman, a city in the south east of Iran. The mother tongue of all learners was Farsi, with six years of studying English at high school level. They were all females, aged 16 to 18 . To homogenize the population, Basic Oxford Placement Test (2003) was administered and a sample of 46 made up the subjects who established the experimental group (EG: $n=22)$ and the other control group (CG: $n=24)$. The researcher used availability sampling procedures in order to select the participants of the study.

\section{Instrumentation}

In order to collect the data of the study, two instruments were used: test of homogenization and writing test. Oxford Basic Test (2002) was used to homogenize the participants of the two groups. The next instrument was implementing writing test that was used both as pre and posttest in order to tap the writing level of the participants both at the beginning of the study and at the end after they had received the treatment. The test condition in terms of the allotted time, topic and scoring strategies were kept the same for both groups.

To improve the reliability of the writing scores, the researcher increased the number of raters to two (Brown \& Abeywickrama, 2010) and (Brown, 2005) and (Heaton, 1988) and 
(Hamp-Lyone, 2000) and thus each candidate's paper was assessed by two independent raters as well as the researcher herself. In addition, the raters were instructed by the researcher to follow a holistic or impression approach in rating the subjects' papers (Heaton, 1988); (Fulcher \& Davidson, 2007).

To estimate the reliability of the scores offered by the three different raters, internal consistency of the scores were estimated using Spearman Correlation.

To estimate the content validity of the questionnaire after being translated, it was back translated into English by an expert of translation and in several cases, some problems were observed that were removed and the edited version was used.

To estimate the reliability of the questionnaire, the researcher used Chronbach's Alfa. It is an approach, as (Brown \& Hudson, 2003) discussed, to establishing reliability using a formula studying the relationship between item numbers of the questionnaire, variance of the total scores, and the proportion of the examinees who responded positively or negatively. Finally, it was proved to be reliable at .89 that was considered high enough.

\section{Metacognitive Strategy Teaching}

To present metacognitive strategies, the teacher explained what the strategy was, why it was a useful, and how and when it was to be used. Thus the teacher incorporated three guidelines for EFL learners in her writing class. The first step was explicit instruction. As (Salehi \& Farzad, 2003) emphasized the important role metacognition plays in academic learning, and recommended direct instruction as one effective classroom practice that would help students to develop their metacognitive awareness. To this goal, the teacher summarized five key features which focused on explanations of how to learn metacognitively.

The second step was scaffolded instruction. The instructional goal for the students was to be able to self-regulate their own learning eventually without external support. Thus the teacher in this step adopted scaffolded instruction to provide students with guided practice until their metacognitive strategies moved toward an automatic state. Scaffolding involves providing support to students to bridge the gap between what they can do on their own and what they can do with guidance from more competent others including teachers and peers.

As the final step, the teacher paid attention to the fact that metacognitive instruction needed to be an integral part of the instructional objectives and could be achieved within a long time of practice and activities. Thus the writing class was exposed to the metacognitive awareness procedures over an entire school year. It was basically important in this study that the teachers had to implement metacognitive instruction in her classroom with a lot of patience. (Garner, 1988) and (Hartman, 2001) and (Salehi \& Farzad, 2003) and (Sitko, 1998) all advise that metacognitive instruction takes up a great deal of class time, and that sometimes students' progress and improvement are hard to be observed. Thus, both teacher and students needed much patience and persistence to practice the series of teaching activities.

\section{Results and Discussion}

The data in (Table 1) and (Table 4) that present the pre and posttest results for both CG and EG can reveal the result. As (Table 1) shows, the mean score for 24 learners of the CG was estimated to be 7.45. In fact the pretest was taken before any instruction and since the learners of the CG had very little idea about English writing, their mean was very low. The highest score was 12 out of 20 compared with the lowest one that was 5 . 
Table 1.

Data of Pretest of Writing for $C G$

\begin{tabular}{lccccc}
\hline ROW & N & Minimum & Maximum & Mean & Std. Deviation \\
\hline & & & & & \\
\hline Pretest of CG & 24 & 5.00 & 12.00 & 7.4583 & 1.81729 \\
\hline Valid N (listwise) & 24 & & & & \\
\hline
\end{tabular}

On the other hand, (Table 2) presents the post test data for the CG. As the data shows, the mean for the posttest of the CG was estimated to be 10.83 that was higher than the pretest score; however, it was not estimated to be satisfactory.

Table 2.

Data of Posttest of Writing for CG

\begin{tabular}{cccccc}
\hline ROW & N & Minimum & Maximum & Mean & Std. Deviation \\
\hline Posttest of CG & 24 & 7.00 & 15.00 & 10.8333 & 2.09900 \\
\hline Valid N (listwise) & 24 & & & & \\
\hline
\end{tabular}

(Table 3) presents the data on pretests of the EG. It shows the mean for the 22 learners of the EG was calculated to be 9.54. The highest score of this group was estimated to be 15 and the lowest was 5. Before any instruction, the learners had no idea about writing and thus the scores were very low.

\section{Table 3.}

Data of Pretest of Writing for EG

\begin{tabular}{cccccc}
\hline ROW & N & Minimum & Maximum & Mean & Std. Deviation \\
\hline Pretest for EG & 22 & 5.00 & 15.00 & 9.5455 & 2.55841 \\
\hline Valid N (listwise) & 22 & & & & \\
\hline
\end{tabular}

After receiving the instruction on writing and being helped to implement the principles of metacognitive awareness in the writing class, the mean for the EG was estimated to be 14.77. As it can be seen, the raise from 9.54 to 14.77 can be seen. The highest score for this group was 17 out of 20 compared with the lowest one that was 9. The change in the mean score of this group can be related to both writing improvement of the learners and also it can show the effect of MAI. The data are presented in (Table 4).

Table 4.

Data of Posttest of Writing for EG

\begin{tabular}{lccccc}
\hline \multicolumn{1}{c}{ ROW } & N & Minimum & Maximum & Mean & Std. Deviation \\
\hline Posttest for EG & 22 & 9.00 & 17.00 & 14.7727 & 2.42864 \\
\hline Valid N (listwise) & 22 & & & & \\
\hline
\end{tabular}


Moreover, a part of the data is the inferential data that is presented in tables 4.5 to 4.8 . According to these tables, the relationship between the pre and posttests of writing were investigated. In this way, data in (Table 5) indicates that there is meaningful relationship between pre and post writing tests for the CG. In fact, the use of teaching procedures for this groups has been effective enough to impact the writing progress of the learners among the CG.

Table 5.

Data on Paired Samples Test for the CG

\begin{tabular}{|c|c|c|c|c|c|c|c|c|c|}
\hline \multirow{3}{*}{\multicolumn{2}{|c|}{ ROW }} & \multicolumn{5}{|c|}{ Paired Differences } & \multirow[t]{3}{*}{$\mathrm{t}$} & \multirow[t]{3}{*}{ df } & \multirow{3}{*}{$\begin{array}{l}\text { Sig. (2- } \\
\text { tailed) }\end{array}$} \\
\hline & & \multirow[t]{2}{*}{ Mean } & \multirow[t]{2}{*}{$\begin{array}{c}\text { Std. } \\
\text { Deviation }\end{array}$} & \multirow[t]{2}{*}{$\begin{array}{l}\text { Std. } \\
\text { Error } \\
\text { Mean }\end{array}$} & \multicolumn{2}{|c|}{$\begin{array}{l}\text { 95\% Confidence } \\
\text { Interval of the } \\
\text { Difference }\end{array}$} & & & \\
\hline & & & & & Lower & Upper & & & \\
\hline $\begin{array}{c}\text { Pair } \\
1\end{array}$ & $\begin{array}{c}\text { Pre \& } \\
\text { posttest }\end{array}$ & -3.37500 & 1.58286 & 0.32310 & -4.04338 & -2.70662 & -10.446 & 23 & 0.000 \\
\hline
\end{tabular}

(Table 6) offers the data for the pre and posttest of the EG. Based on the data, the $\operatorname{sig}=0.000$ that is smaller than .05 . It shows that there is meaningful relationship between the pre and post writing tests of the EG. In fact, the treatment of using MAI was effective enough for the learners in the EG to impact their writing skill in a positive manner.

Table 6.

Paired Samples Test for the EG

\begin{tabular}{|c|c|c|c|c|c|c|c|c|c|}
\hline \multirow{3}{*}{\multicolumn{2}{|c|}{ ROW }} & \multicolumn{5}{|c|}{ Paired Differences } & \multirow[t]{3}{*}{$\mathrm{t}$} & \multirow[t]{3}{*}{$\mathrm{df}$} & \multirow{3}{*}{$\begin{array}{l}\text { Sig. (2- } \\
\text { tailed) }\end{array}$} \\
\hline & & \multirow[t]{2}{*}{ Mean } & \multirow[t]{2}{*}{$\begin{array}{l}\text { Std. Devia- } \\
\text { tion }\end{array}$} & \multirow[t]{2}{*}{$\begin{array}{l}\text { Std. Error } \\
\text { Mean }\end{array}$} & \multicolumn{2}{|c|}{$\begin{array}{l}\text { 95\% Confidence Interval } \\
\text { of the Difference }\end{array}$} & & & \\
\hline & & & & & Lower & Upper & & & \\
\hline $\begin{array}{c}\text { Pair } \\
1\end{array}$ & $\begin{array}{c}\text { Pre \& } \\
\text { posttest }\end{array}$ & -4.22727 & 1.79767 & 0.38326 & -5.02431 & -3.43023 & -11.030 & 21 & 0.000 \\
\hline
\end{tabular}

On the other hand, the data in (Table 7) presents the result of independent sample $t$ test for the EG and CG pretest. Based on the data, there is meaningful relationship between the two tests: sig $=0.05$ that indicated the meaningful relationship between the two tests.

Table 7.

Independent Samples Test for pretests (CG-EG)

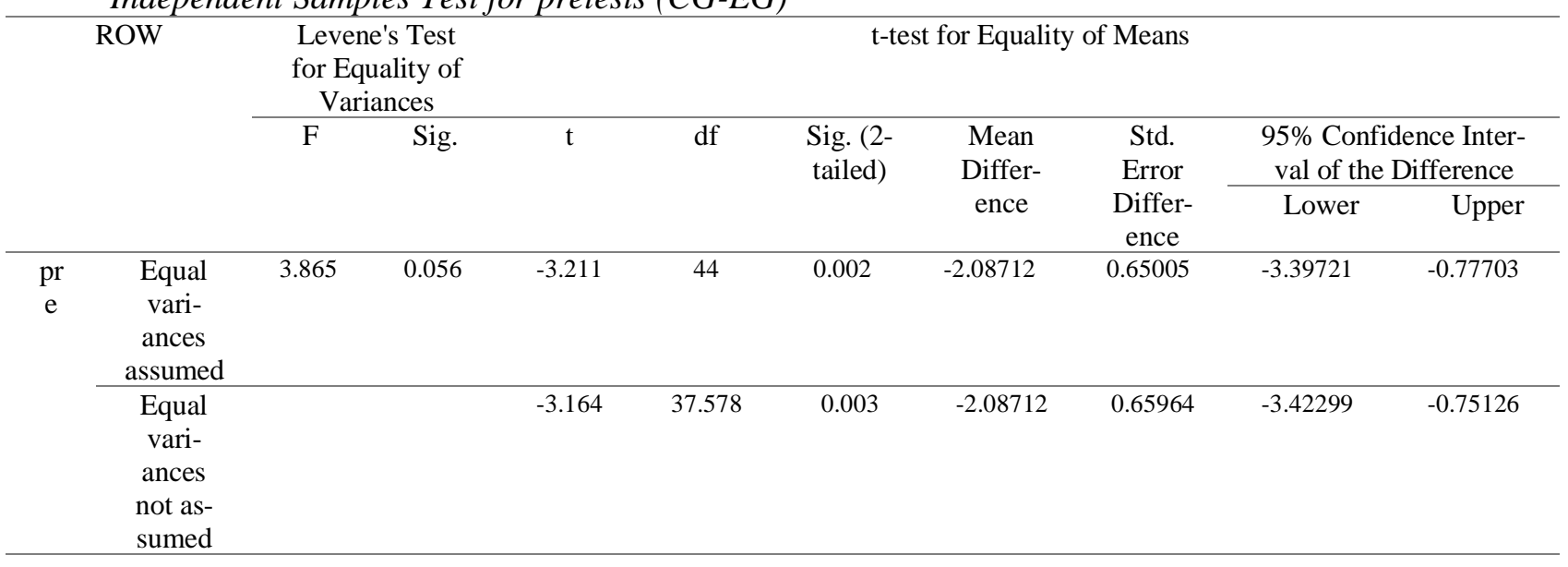


(Table 8) offers the data of independent sample $t$ test for the posttests of EG and CG. As the data reveals, the level of significance for the two groups was calculated to be .001 that shows there is meaningful relationship between the two posttests.

\section{Table 8.}

Independent Samples Test for posttests (CG-EG)

\begin{tabular}{|c|c|c|c|c|c|c|c|c|c|c|}
\hline & \multirow{3}{*}{ ROW } & \multicolumn{2}{|c|}{$\begin{array}{c}\text { Levene's Test } \\
\text { for Equality of } \\
\text { Variances }\end{array}$} & \multicolumn{7}{|c|}{ t-test for Equality of Means } \\
\hline & & \multirow[t]{2}{*}{$\mathrm{F}$} & \multirow[t]{2}{*}{ Sig. } & \multirow[t]{2}{*}{$\mathrm{t}$} & \multirow[t]{2}{*}{$\mathrm{df}$} & \multirow[t]{2}{*}{$\begin{array}{l}\text { Sig. } \\
(2- \\
\text { tailed })\end{array}$} & \multirow[t]{2}{*}{$\begin{array}{l}\text { Mean Dif- } \\
\text { ference }\end{array}$} & \multirow{2}{*}{$\begin{array}{l}\text { Std. } \\
\text { Error } \\
\text { Differ- } \\
\text { ence }\end{array}$} & \multicolumn{2}{|c|}{$\begin{array}{l}\text { 95\% Confidence In- } \\
\text { terval of the Differ- } \\
\text { ence }\end{array}$} \\
\hline & & & & & & & & & Lower & Upper \\
\hline \multirow[b]{2}{*}{ pos } & $\begin{array}{c}\text { Equal } \\
\text { variances } \\
\text { assumed }\end{array}$ & 2.433 & 0.126 & -3.690 & 44 & 0.001 & -2.62121 & 0.71027 & -4.05267 & -1.18975 \\
\hline & $\begin{array}{c}\text { Equal } \\
\text { variances } \\
\text { not as- } \\
\text { sumed }\end{array}$ & & & -3.650 & $\begin{array}{c}39.5 \\
87\end{array}$ & 0.001 & -2.62121 & 0.71814 & -4.07310 & -1.16932 \\
\hline
\end{tabular}

\section{Discussion of Research Hypotheses}

According to the data presented in chapter 4, writing achievement among the two groups that were exposed to two types of instructions was significantly different. As it was learned, the difference between the means of the two pre and post writing tests were significant enough to reveal both the two groups' improvement as well as showing the meaningful relationship between the two pre and posttests. The mean for the learners of the EG was calculated to be 9.54 that after receiving the MAI, it changed to 14.77 for the post writing test. After receiving the instruction on writing and being helped to implement the principles of metacognitive awareness in the writing class, the mean for the EG increased significantly. The difference between the means of the two tests indicated more learning and therefore, it can mean the impact of MAI and its impact on the writing ability of the learners. Moreover, the inferential data also indicated the significant difference between the writing performance of the learners of the EG from pre to posttest. In fact, the learners' performance was impacted significantly by the use of MAI in the writing class. The data showed that the writing improvement from pre to post writing test was significant and had positive impact on the performance of the learners. According to the data, the relationship between the pre and posttests of writing of the two tests was investigated. In this way, the data indicated that there is meaningful relationship between pre and post writing tests for the EG. In fact the use of teaching procedures for this groups has been effective enough to impact the writing proficiency. The treatment of using MAI was effective enough for the learners in the EG to impact their writing skill positively.

\section{Conclusion}

The goal of this study was implementing metacognitive awareness instruction in the writing class in order to enhance high school EFL learners' writing skill. In fact, the goal was introducing the teaching procedures in the writing class being based on improving and fostering the metacognitive awareness of the learners. The study clearly revealed that teaching metacognitive procedures had positive impact on the input of the learners and was effective enough to impact both aspects of their linguistic and non-linguistic aspects. On the one hand, teaching the principles helped the learners to feel their progress in the writing skill, with which they have had a lot 
of problems. It was the most outstanding achievement of the study since it could achieve and fulfill one of the most important objectives that the study meant to achieve. Regarding the attitudes of the subjects, it can be concluded that the learners felt both positive and negative about the use of the MAI procedures. Since the learners were not familiar with the use of the procedures and it was for the first time that they were exposed to these procedures, it seemed to be hard for them to adapt themselves to the principles. However, in many cases, they asserted that they were satisfied with the use of the principle in their writing class. They specially believed that the procedures were motivating and thus led to their success in writing.

\section{References}

Renee Payne A. (2007), Development of the Academic Writing Motivation Questionnaire, (Master's thesis), Unpublished Dissertation, University of Georgia, 19(5): 130-142.

Richards J. \& Schmidt R. (2010), Longman dictionary of language teaching and applied linguistics, London: Longman (Pearson Education), 16(5): 56-67.

Skehan P. (1989), Individual Differences in Second Language Acquisition. London: Edward Arnold, 15(2): 140-153.

Riding R. \& Rayner S. (2000), Cognitive styles and learning strategies: understanding style differences in learning and behaviour. London: David Fulton, 18(1): 78-100.

Ehrman M. (1996) Understanding Second Language Difficulties. California, U.S.A: Sage Publications, Inc, 9(6): 27-36.

Öz H. (2005), Metacognition in foreign / second language learning and teaching, Hacettepe University Journal of Education, 29(3):147-156.

Flavell J. (1987), Speculation about the nature and development of metacognition. In F. Weinert \& R. Kluwe (Eds.), Metacognition, motivation, and understanding, Hillsdale, NJ: Lawrence Erlbaum, 29(3): 21-29.

Schraw G. (1998), Promoting metacognitive awareness. International Science, 2(6): 113-125.

Wenden A. (1998), Metacognitive Knowledge and Language Learning, Applied Linguistics, 19(4): 515-537.

Flavell J. (1979), Metacognition and cognitive monitoring: A new area of cognitivedevelopmental inquiry. American Psychologist, 34(6): 906-911.

Brown A. (1987), Metacognition, executive control, self-regulation, and other more mysterious mechanisms, In F. Weinert \& R. Kluwe (Eds.), Metacognition, motivation, and understanding, Hillsdale, NJ: Erlbaum, 14(5): 65-116.

Wenden A. \& Rubin J. (1987), Learner Strategies for Language Learning. Englewood Cliffs, NJ. Prentice Hall, 26(1): 130-145.

Schraw G. \& Denison R. (1994), Assessing Metacognitive Awareness. Contemporary Educational Psychology, 19(2): 460-475.

Oxford R. (1990). Language learning strategies: What every teacher should know, New York: Newbury House Publishers, 18(9): 152-167.

Cohen A. (1998), Strategies in Learning and Using a Second Language. Addison Wesley. Essex: Longman, 28(1): 69-80.

Gold D. \& Hobbs C. \& Berlin J. (2012), Writing instruction in school and college English. In J. J. Murphy (Ed.), New York: Routledge, A short history of writing instruction: From ancient Greece to contemporary America, 16(2): 232-272.

Mohanty S. (2007). Lifelong and adult education, New Delhi: Ashish Publishing House, 19(1): 311-320.

Hairston M. (1982), The winds of change: Thomas Kuhn and the revolution in the teaching of writing. College Composition and Communication, 33(5): 76-88.

Johns A. (1990), L1 composition theories: Implications for developing theories of L2 composition. In B. Kroll (Ed.), Second language writing: Research insights for the classroom, Cambridge: Cambridge University Press, 17(4): 24-36.

Hayes J. \& Flower L. (1980), Identifying the organization of writing processes. In L. Gregg \& E. Steinberg (Eds.), Cognitive processes in writing, Hillsdale, NJ: Erlbaum, 9(1): 3-30. 
Bereiter C. \& Scardamalia M. (1987), The psychology of written composition, Hillsdale, NJ: Lawrence Erlbaum Associates, 11(3): 79-98.

Wong B. (1991), The conceptual perspectives in the connections between reading and writing processes. In A. McKeough \& J. L. Lupart (Eds.), Toward the practice of theory-based instruction. Current cognitive theories (p. 66-93). Hillsdale, NJ: Lawrence Erlbaum, 19(1): 159-170.

Hartman H. (2001), Developing students' metacognitive knowledge and skills. In H.J. Hartman Metacognition in learning and instruction: Theory, research and practice, Boston: Kluwer Academic, 15(8): 33-68.

Jacobs J. \& Paris S. (1987), Children's metacognition about reading: Issues in definition, measurement, and instruction. Educational Psychologist, (22): 225-278.

Wu X. (2003), Intrinsic motivation and young learners: The impact of the classroom environment. System, 23(1): 32-55.

Dornyei Z. \& Clement R. (2001), Motivational characteristics of learning different target languages: results of a nationwide survey. In: Do“ rnyei, Z., Schmidt, R. (Eds.), Motivation and Second Language Acquisition, University of Hawai'i, Second Language Teaching and Curriculum Center, Honolulu, HI, 15(1): 399-432.

Brown D. \& Abeywickrama P. (2010), Language Assessment, Principles and Classroom Practices. NY: Pearson, 18(2): 78-96.

Brown J. (2005), Testing in Language Programs, A comprehensive Guide to English Language Programs. Singapore: McGraw Hill, 9(1): 401-428.

Heaton J. (1988), Writing English Language Tests, Longman Handbook for Language Teachers (New Edition), London: Longman Group UK Ltd, 16(6): 316-328.

Hamp-Lyone L. (2000), Fairness in language testing, In Kunnan, A. J. (ed). Fairness and validation in Language Assessment, Studies in Language Testing 9, Cambridge: Cambridge University Press, 4(3): 30-34.

Fulcher G. \& Davidson F. (2007), Language Testing and Assessment, an advanced resource book. GB: Routledge, 17(1): 75-83.

Brown J. \& Hudson T. (2003), Criterion-referenced Language Testing. London: Cambridge Applied Linguistics, 14(5): 105-116.

Salehi R. \& Farzad V. (2003), The relationship between metacognitive knowledge, learning conception and learning English, Journal of Psychology, 7(3): 270-286.

Garner R. (1988), Metacognition and reading comprehension, Norwood, NJ: Ablex Publishing, 16(4): 169-175.

Sitko B. (1998), Knowing how to write: Metacognition and writing instruction, In D. J. Hacker, J. Donlosky \& A. C. Graesser (Eds.), Metacognition in educational theory and practice, Mahwah, NJ: Erlbaum, 15(6): 93-115. 